Journal of Organometallic Chemistry, 314 (1986) 131-138

Elsevier Sequoia S.A., Lausanne - Printed in The Netherlands

\title{
PHENOXOTANTALUM(V) COMPLEXES
}

\author{
M. GÓMEZ, P. ROYO and J.M. SELAS
}

Departamento de Quimica Inorgánica, Universidad de Alcalá de Henares (Spain)

(Received April 23rd, 1986)

\section{Summary}

The reaction of the compounds $\mathrm{TaXCl}_{4}\left(\mathrm{X}=\eta^{5}-\mathrm{C}_{5} \mathrm{H}_{5}, \eta^{5}-\mathrm{C}_{5} \mathrm{H}_{4} \mathrm{SiMe}_{3}\right.$ or $\left.\mathrm{Cl}\right)$ with o-diphenols 4- $\mathrm{RC}_{6} \mathrm{H}_{3}(\mathrm{OH})_{2} \quad\left(\mathrm{R}=\mathrm{H}, \mathrm{Me}, \quad \mathrm{Bu}^{\mathrm{t}}\right)$ gave the dialkoxides $\mathrm{XCl}_{2} \mathrm{Ta}\left(\mathrm{O}_{2} \mathrm{C}_{6} \mathrm{H}_{3} \mathrm{R}\right)$, whereas the reaction with $4,4^{\prime}$-isopropylidenediphenol gave the monoalkoxides $\left[\mathrm{TaXCl}_{3}\right]_{2}\left[\left(\mathrm{OC}_{6} \mathrm{H}_{4}\right)_{2} \mathrm{CMe}_{2}\right]$. Osmometry shows the cyclopentadienyl derivatives with $\mathrm{X}=\eta^{5}-\mathrm{C}_{5} \mathrm{H}_{4} \mathrm{SiMe}_{3}$ and $\mathrm{R}=\mathrm{Me}, \mathrm{Bu}^{\mathrm{t}}$ to be dimeric in benzene, but the halogeno complex with $\mathrm{X}=\mathrm{Cl}$ and $\mathrm{R}=\mathrm{Bu}^{1}$ to be trimeric. The new alkoxide complexes have been characterised by IR and ${ }^{1} \mathrm{H}$ and ${ }^{13} \mathrm{C}$ NMR spectroscopy.

\section{Introduction}

There is increasing interest in the chemistry of monocyclopentadienyl derivatives of the first group transition metals [1]. Many coordinatively unsaturated organo complexes of this type can be readily obtained by use of bulky ligands. Various alkoxo ligands have been used to stabilize high oxidation states and there have been numerous studies of the catalytic activity of these compounds in alkene [2] and methyl metacrylate [3] polymerization and particularly in alkene metathesis [4]. The ability of the alkoxo groups to form double or triple $\mu$-oxo bridges leads to coordinatively saturated complexes when the alkoxo group substituent is not especially bulky. We describe here results observed in reactions of 4-R-substituted o-diphenols with $\mathrm{TaXCl}_{4}\left(\mathrm{X}=\eta^{5}-\mathrm{C}_{5} \mathrm{H}_{5}, \eta^{5}-\mathrm{C}_{5} \mathrm{H}_{4} \mathrm{SiMe}_{3}\right.$ or $\left.\mathrm{Cl}\right)$.

\section{Results and discussion}

The compound $\mathrm{Ta}\left(\eta^{5}-\mathrm{C}_{5} \mathrm{H}_{4} \mathrm{SiMe}_{3}\right) \mathrm{Cl}_{4}$, I, was made by two methods, the first involving $\mathrm{Sn}\left(\mathrm{C}_{5} \mathrm{H}_{4} \mathrm{SiMe}_{3}\right) \mathrm{Bu}_{3}^{\mathrm{n}}$ (prepared by a modification of the procedure reported for $\left.\mathrm{Sn}\left(\mathrm{C}_{5} \mathrm{H}_{5}\right) \mathrm{Bu}_{3}^{\mathrm{n}}[5]\right)$ and the second $\mathrm{C}_{5} \mathrm{H}_{4}\left(\mathrm{SiMe}_{3}\right)_{2}$ [6], as the source of the trimethylsilylcyclopentadienyl ligand. Dropwise addition of the tin or silicon re-

* This paper is dedicated to Prof. R. Usón on his 60 th birthday. 
TABLE 1

ANALYTICAL COMPOSITION AND PHYSICAL DATA FOR PHENOXO-TANTALUM(V) COMPLEXES

\begin{tabular}{|c|c|c|c|c|c|}
\hline \multirow[t]{2}{*}{ Complex } & \multirow[t]{2}{*}{ Colour } & \multicolumn{2}{|c|}{ Analysis (Found (calcd.)(\%)) } & \multirow[t]{2}{*}{ Yield (\%) } & \multirow{2}{*}{$\begin{array}{l}\text { Molec. weight } \\
\text { Found. (calcd.) }\end{array}$} \\
\hline & & $\mathrm{C}$ & $\mathrm{H}$ & & \\
\hline I & Yellow-dark & $\begin{array}{c}20.7 \\
(20.9)\end{array}$ & $\begin{array}{c}3.0 \\
(2.8)\end{array}$ & 80 & - \\
\hline II & Green & $\begin{array}{c}30.7 \\
(31.0)\end{array}$ & $\begin{array}{c}2.2 \\
(2.1)\end{array}$ & 75 & - \\
\hline III & Green & $\begin{array}{c}32.7 \\
(32.8)\end{array}$ & $\begin{array}{c}2.7 \\
(2.5)\end{array}$ & 75 & - \\
\hline IV & Green & $\begin{array}{c}37.2 \\
(37.4)\end{array}$ & $\begin{array}{c}3.6 \\
(3.6)\end{array}$ & 90 & - \\
\hline $\mathrm{V}$ & Green-dark & $\begin{array}{c}34.0 \\
(33.8)\end{array}$ & $\begin{array}{c}3.6 \\
(3.4)\end{array}$ & 80 & - \\
\hline VI & Red-dark & $\begin{array}{c}35.1 \\
(35.2)\end{array}$ & $\begin{array}{c}3.7 \\
(3.7)\end{array}$ & 90 & $1000(511)$ \\
\hline VII & Red-dark & $\begin{array}{c}38.9 \\
(39.1)\end{array}$ & $\begin{array}{c}4.4 \\
(4.6)\end{array}$ & 85 & $1138(553)$ \\
\hline VIII & Orange & $\begin{array}{c}20.1 \\
(18.2)\end{array}$ & $\begin{array}{c}1.8 \\
(1.0)\end{array}$ & 65 & - \\
\hline IX & Orange & $\begin{array}{c}21.6 \\
(20.5)\end{array}$ & $\begin{array}{c}2.3 \\
(1.5)\end{array}$ & 65 & - \\
\hline $\mathrm{X}$ & Orange & $\begin{array}{c}28.6 \\
(26.6)\end{array}$ & $\begin{array}{c}2.9 \\
(2.7)\end{array}$ & 67 & $1390(518)$ \\
\hline $\mathrm{XI}$ & Brown & $\begin{array}{c}32.4 \\
(32.3)\end{array}$ & $\begin{array}{c}2.6 \\
(2.6)\end{array}$ & 95 & - \\
\hline XII & Green & $\begin{array}{c}33.8 \\
(34.6)\end{array}$ & $\begin{array}{c}3.7 \\
(3.7)\end{array}$ & 90 & - \\
\hline
\end{tabular}

${ }^{a}$ In benzene solution

agents to a toluene solution of $\mathrm{TaCl}_{5}$ led to the formation of complex I which was isolated in $80 \%$ yield.

Reactions of $\mathrm{TaXCl}_{4}\left(\mathrm{X}=\eta^{5}-\mathrm{C}_{5} \mathrm{H}_{5}, \eta^{5}-\mathrm{C}_{5} \mathrm{H}_{4} \mathrm{SiMe}_{3}, \mathrm{Cl}\right)$ with $\mathrm{LiOBu}^{\mathrm{t}}$ and with alcohols such as $\mathrm{Bu}^{t} \mathrm{OH} ; 2,3,5-\mathrm{Me}_{3} \mathrm{C}_{6} \mathrm{H}_{2} \mathrm{OH}$ and $2,3,5-\mathrm{Bu}_{3}^{t} \mathrm{C}_{6} \mathrm{H}_{2} \mathrm{OH}$ in various molar ratios gave solutions from which solids containing a mixture of halo-alkoxo complexes with various degrees of substitution were obtained. However, new chelate diphenoxo tantalum(V) complexes were obtained by heating a toluene solution of a mixture of $\mathrm{TaXCl}_{4}\left(\mathrm{X}=\eta^{5}-\mathrm{C}_{5} \mathrm{H}_{5}, \eta^{5}-\mathrm{C}_{5} \mathrm{H}_{4} \mathrm{SiMe}_{3}, \mathrm{Cl}\right)$ and various 4-R-o-diphenols in $1 / 1$ molar ratio, according to eq. 1.

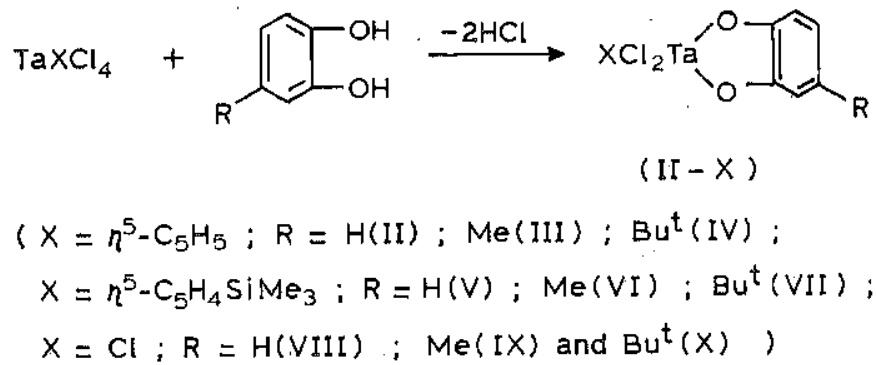


Complexes II-IV are only slightly soluble in toluene and benzene and moderately soluble in methanol, whereas $\mathrm{V}-\mathrm{X}$ are readily soluble in toluene, benzene and chloroform. They are not very stable in air, since they are readily hydrolyzed, and reaction takes place in polar solvents; the possibility of isolating adducts with $\mathrm{N}$ and $\mathrm{O}$ donors is being studied.

A similar reaction with $4,4^{\prime}$-isopropylidenediphenol in a $2 / 1$ molar ratio gave very insoluble solids which were identified as the monoaryloxo compounds (eq. 2).

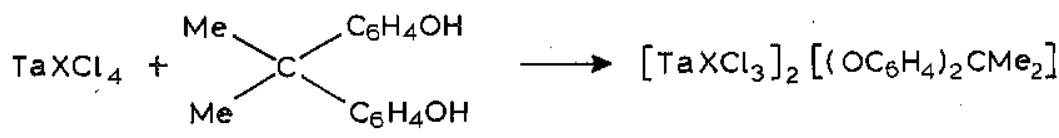

$$
\left(x=\eta^{5}-C_{5} H_{5}(X I) ; \eta^{5}-C_{5} H_{4} \operatorname{SiMe}_{3}(X I I)\right)
$$

Complexes XI-XII are only slightly soluble in methanol.

All the compounds gave satisfactory analyses (see Table 1).

\section{Infrared spectra}

All the spectra show the characteristic absorption bands of the $\eta^{5}$-cyclopentadienyl group [7], the most significant being the bands at $850-860 \mathrm{~cm}^{-1}$ for the $\eta^{5}$-cyclopentadienyl ring and that at $1260-1275 \mathrm{~cm}^{-1}$ for the trimethylsilyl group [8]. They also show bands due to the internal vibrations of the alkoxo groups. Other bands assignable to the metal-chlorine bonds and to the $\mathrm{C}-\mathrm{O}-\mathrm{Ta}$ system are shown in Table 2. The $\nu(\mathrm{Ta}-\mathrm{Cl})$ stretching vibrations appear between 305 and $360 \mathrm{~cm}^{-1}$ [9], although in complexes involving $\eta^{5}-\mathrm{C}_{5} \mathrm{H}_{4} \mathrm{SiMe}_{3}$, the presence of absorptions due to the $\mathrm{SiMe}_{3}$ group [10] makes definitive assignment more difficult. The region between 900 and $1125 \mathrm{~cm}^{-1}$ contains two or more bands which must be assigned to $\nu(\mathrm{C}-\mathrm{O})$ vibrations and there are always two in the region $470-590 \mathrm{~cm}^{-1}$ which can be assigned to $\nu(\mathrm{M}-\mathrm{O})$ [11]. Many studies of these two regions have been made in

TABLE 2

SELECTED IR BANDS (Nujol mulls) $\left(\mathrm{cm}^{-1}\right)$ FOR PHENOXO-TANTALUM(V) COMPLEXES

\begin{tabular}{llll}
\hline Complex & $\nu(\mathrm{Ta}-\mathrm{Cl})$ & $\nu(\mathrm{C}-\mathrm{O})$ & $\nu(\mathrm{Ta}-\mathrm{O})$ \\
\hline I & $315 \mathrm{vs,b}$ & $930 \mathrm{~m} ; 1025 \mathrm{~s}$ & $545 \mathrm{~m} ; 475 \mathrm{w}$ \\
II & $320 \mathrm{~s}, \mathrm{~b}$ & $1125 \mathrm{~m} ; 1015 \mathrm{~m}$ & $590 \mathrm{w} ; 475 \mathrm{w}$ \\
& & $950 \mathrm{~m} ; 900 \mathrm{~m}$ & \\
III & $320 \mathrm{vs}, \mathrm{b}$ & $1075 \mathrm{w} ; 975 \mathrm{~m} ; 900 \mathrm{w}$ & $585 \mathrm{~m} ; 470 \mathrm{~m}$ \\
IV & $310 \mathrm{~s}$ & $9100 \mathrm{~s}, \mathrm{~b} ; 1025 \mathrm{~s}, \mathrm{~b}$ & $580 \mathrm{w} ; 525 \mathrm{w}$ \\
& & $1090 \mathrm{~s}, \mathrm{~b} ; 915 \mathrm{~s}$ & $515 \mathrm{~m}$ \\
V & $325 \mathrm{vs}$ & $1120 \mathrm{~s}, \mathrm{~b} ; 1050 \mathrm{~s}, \mathrm{~b}$ & $565 \mathrm{w} ; 505 \mathrm{~m}$ \\
VI & $305 \mathrm{~s}, \mathrm{~b}$ & $950 \mathrm{~s}$ & \\
& $345 \mathrm{vs,vb}$ & $1210 \mathrm{~m} ; 1060 \mathrm{~s}$ & $590 \mathrm{~s} ; 540 \mathrm{~s} ; 470 \mathrm{~m}$ \\
VII & $930 \mathrm{~s} ; 890 \mathrm{~m}$ & $585 \mathrm{w} ; 555 \mathrm{w} ; 470 \mathrm{w}$ \\
VIII & $1125 \mathrm{~s} ; 1105 \mathrm{~s}$ & $560 \mathrm{w} ; 495 \mathrm{vw}$ \\
IX & $360 \mathrm{vs}, \mathrm{b}$ & $1015 \mathrm{~m} ; 935 \mathrm{~m}$ & \\
& $355 \mathrm{vb}$ & $900 \mathrm{~m}, \mathrm{~b}$ & \\
\hline
\end{tabular}


order to distinguish between terminal and bridge alkoxo groups [12] but complexity of the absorption bands observed precludes definitive assignment for our complexes, which probably contain both terminal and bridge systems.

\section{NMR spectra and structural assignment}

Table 3 gives ${ }^{1} \mathrm{H}$ NMR data, Table 4 the ${ }^{13} \mathrm{C}$ NMR data.

The ${ }^{1} \mathrm{H}$ spectrum of complex I shows a multiplet between $\delta 6.50$ and $6.68 \mathrm{ppm}$ for the cyclopentadienyl protons and a singlet due to the $\mathrm{SiMe}_{3}$ group at $\delta 0.10 \mathrm{ppm}$ in benzene- $d_{6}$. The ${ }^{13} \mathrm{C}$ spectrum of this compound shows only two resonances for the ring carbon atoms instead of the expected three observed for similar complexes [13]. The less intense signal at $\delta 127.5 \mathrm{ppm}$ must be assigned to the substituted carbon atom, whereas the more intense at $\delta 126.7 \mathrm{ppm}$ corresponds to the remaining four carbon atoms which are unexpectedly equivalent or so similar that they cannot be distinguished by our spectrometer. The $\mathrm{SiMe}_{3}$ carbon atoms give a singlet at $\delta$ $0.27 \mathrm{ppm}$. From these data it seems that I may have a four-legged piano stool structure, although some type of association by chlorine bridges cannot be discounted.

The IR spectra of the alkoxo cyclopentadienyl complexes II-VII suggest the presence of only terminal metal-chlorine bonds, but bridging alkoxo groups could be present. Molecular weights measurements in benzene gave values of 1000 (calcd. 511) and 1138 (calcd. 553) for VI and VII, respectively, confirming the dimeric nature of these compounds. This is also confirmed by the NMR studies, and in this

\section{TABLE 3}

${ }^{1}$ H NMR DATA FOR PHENOXO-TANTALUM(V) COMPLEXES ( $\delta(\mathrm{ppm})$ with respect to TMS (multiplicity))

\begin{tabular}{|c|c|c|c|c|c|c|c|c|}
\hline \multirow[t]{2}{*}{ Complex } & \multirow[t]{2}{*}{ Solvent } & \multirow[t]{2}{*}{$\mathrm{C}_{5} H_{5}$} & \multirow[t]{2}{*}{$\mathrm{C}_{5} H_{4} \mathrm{R}$} & \multirow[t]{2}{*}{$\mathrm{Si} \mathrm{Me}_{3}$} & \multirow[t]{2}{*}{$\mathrm{R}^{\prime} \mathrm{C}_{6} H_{3} \mathrm{O}_{2}$} & \multicolumn{2}{|c|}{$R^{\prime} \mathrm{C}_{6} \mathrm{H}_{3} \mathrm{O}_{2}$} & \multirow[t]{2}{*}{$\mathrm{CMe}_{2}$} \\
\hline & & & & & & $\mathrm{R}^{\prime}=\mathrm{Me}$ & $\mathbf{R}^{\prime}=\mathbf{B u}^{\prime}$ & \\
\hline I & $\begin{array}{l}\mathrm{CDCl}_{3} \\
\mathrm{C}_{6} \mathrm{D}_{6}\end{array}$ & & $\begin{array}{l}a \\
6.68(\mathrm{~m}) \\
6.50(\mathrm{~m})\end{array}$ & $\begin{array}{l}0.38(\mathrm{~s}) \\
0.10(\mathrm{~s})\end{array}$ & & & & \\
\hline II & $\mathrm{CD}_{3} \mathrm{OD}$ & $6.70(s)$ & & & $6.91(\mathrm{~m})$ & & & \\
\hline III & $\mathrm{CD}_{3} \mathrm{OD}$ & $6.60(\mathrm{~s})$ & & & $6.40(\mathrm{~m})$ & $1.80(s)$ & & \\
\hline IV & $\mathrm{CD}_{3} \mathrm{OD}$ & $6.67(\mathrm{~s})$ & & & $6.80(\mathrm{~m})$ & & $1.22(\mathrm{~s})$ & \\
\hline v & $\mathrm{C}_{6} \mathrm{D}_{6}$ & & $\begin{array}{l}7.66(\mathrm{~m}) \\
6.40(\mathrm{~m})\end{array}$ & $0.22(\mathrm{~s})$ & $6.56(\mathrm{~m})$ & & & \\
\hline VI & $\mathrm{C}_{6} \mathrm{D}_{6}$ & & $\begin{array}{l}6.63(b) \\
6.07(b)\end{array}$ & 0.19 (s) & $6.45(\mathrm{~d})$ & $1.83(\mathrm{~s})$ & & \\
\hline VII & $\mathrm{C}_{6} \mathrm{D}_{6}$ & & $\begin{array}{l}6.68(\mathrm{~m}) \\
6.43(\mathrm{t})\end{array}$ & $\begin{array}{l}0.23(\mathrm{~s}) \\
0.25(\mathrm{~s})\end{array}$ & $6.56(b)$ & & $\begin{array}{l}1.18(\mathrm{~s}) \\
1.06(\mathrm{~s})\end{array}$ & \\
\hline $\begin{array}{l}\text { VIII } \\
\text { IX } \\
\text { X }\end{array}$ & $\begin{array}{l}\mathrm{CDCl}_{3} \\
\mathrm{CDCl}_{3} \\
\mathrm{CDCl}_{3}\end{array}$ & & & & $\begin{array}{l}6.45(b) \\
6.93(b) \\
6.90(b)\end{array}$ & $2.37(\mathrm{~m})$ & $1.37(\mathrm{~m})$ & \\
\hline XI & $\mathrm{CDCl}_{3}$ & $6.68(\mathrm{~s})$ & & $0.38(s)$ & $\begin{array}{l}a \\
7.00(\mathrm{~d})\end{array}$ & & & $1.54(\mathrm{~s})$ \\
\hline XII & $\mathrm{CD}_{3} \mathrm{OD}$ & & $a$ & & 6.62(d) & & & $1.50(\mathrm{~s})$ \\
\hline
\end{tabular}

a Overlapped with solvent. 
TABLE 4

${ }^{13} \mathrm{C}-\left({ }^{1} \mathrm{H}\right)$ NMR SPECTRA FOR TANTALUM(V) COMPLEXES

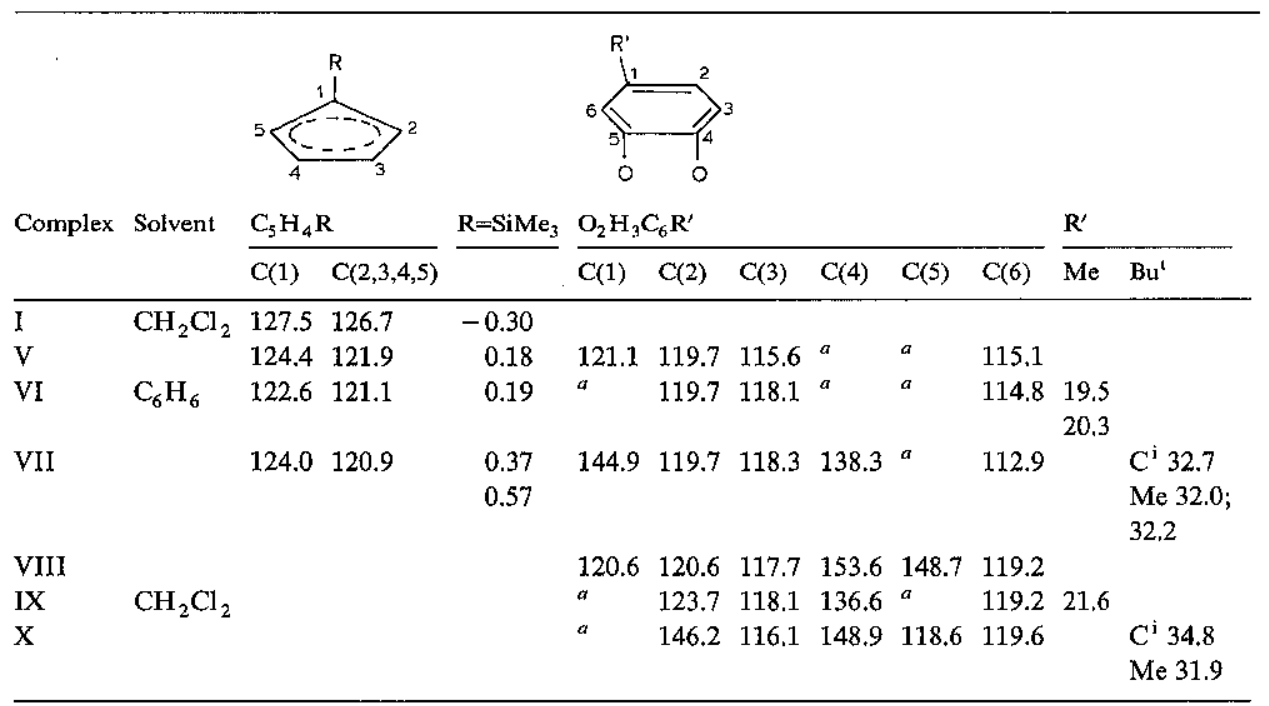

a. Not observed.

respect complex VII deserves special mention. The ${ }^{1} \mathrm{H}$ spectrum of VII shows complex signals for the cyclopentadienyl protons in benzene- $d_{6}$, two singlets for t-butyl at $\delta 1.18$ and $1.06 \mathrm{ppm}$ and also for $\mathrm{SiMe}_{3}$ at $\delta 0.23$ and $0.25 \mathrm{ppm}$, but both $\mathrm{t}-\mathrm{Bu}$ and $\mathrm{SiMe}_{3}$ give only singlets at $\delta 1.02 \mathrm{ppm}$ and $\delta 0.16 \mathrm{ppm}$, respectively, when the spectrum is recorded in MeOH- $d_{4}$. This behaviour confirms that an alkoxo bridge dimer is present in benzene, and that $\mathrm{MeOH}$ cleaves the bridge to give mononuclear species by coordination of the solvent.

The ${ }^{13} \mathrm{C}$ NMR spectrum correspondingly shows two resonances due to the ring carbon atoms, the less intense at $\delta 124.0 \mathrm{ppm}$. being attributed to the substituted carbon atom and the more intense at $\delta 120.9 \mathrm{ppm}$ to the remaining ring carbon atoms, but two singlets are observed for the $\mathrm{SiMe}_{3}$ group, at $\delta 0.37$ and $0.57 \mathrm{ppm}$, and also for the t-butyl substituent, at $\delta 32.0$ and $32.2 \mathrm{ppm}$. A dimeric structure containing two alkoxo bridges formed by two different oxo groups could account for this behaviour.

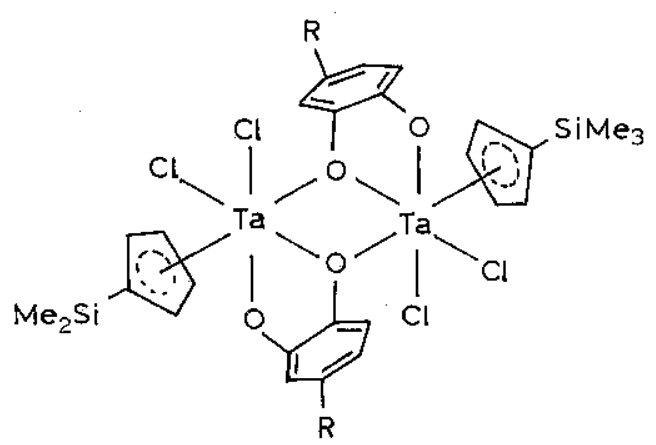


Probably the same structure can be assigned to all complexes II-VII although split signals were not always observed. The ${ }^{1} \mathrm{H}$ spectra of complexes II-IV and XI show a singlet for the cyclopentadienyl protons at $\delta 6.60-6.70 \mathrm{ppm}$, whereas a complex resonance is observed for the ring $\eta^{5}-\mathrm{C}_{5} \mathrm{H}_{4} \mathrm{SiMe}_{3}$ protons at $\delta 6.07-7.66$ $\mathrm{ppm}$ for complexes V-VII and XII. A singlet due to the $\mathrm{SiMe}_{3}$ protons at $\delta$ $0.19-0.38 \mathrm{ppm}$ is also observed for complexes V, VI and XII. The phenyl protons of the alkoxo ligand give a multiplet between $\delta 6.40$ and $7.00 \mathrm{ppm}$. The methyl group of the alkoxo ligand gives a singlet, at $\delta 1.80$ and $1.83 \mathrm{ppm}$, respectively, for III and VI and the t-butyl protons also give a singlet at $\delta 1.22 \mathrm{ppm}$ for IV.

The $\left\{{ }^{1} \mathrm{H}\right\}-{ }^{13} \mathrm{C}$ NMR spectra show only two resonances for the ring carbon atoms for all $\mathrm{C}_{5} \mathrm{H}_{4} \mathrm{SiMe}_{3}$ complexes and a singlet between $\delta 0.18$ and $0.57 \mathrm{ppm}$ for the $\mathrm{SiMe}_{3}$ carbon atoms; two Me resonances at $\delta 19.5$ and 20.3 ppm, are observed for complex VI.

The phenyl carbon atoms of the cathecolate groups give various resonances between $\delta 112.9$ and $153.6 \mathrm{ppm}$ whose chemical shifts are reasonably consistent with values based on expected displacements produced by effect of the substituents on the aromatic ring [14].

No crystals suitable for $\mathrm{X}$-ray diffraction studies could be obtained.

The ${ }^{1} \mathrm{H}$ NMR spectra of the halogeno complexes VIII-X also show a multiplet due to the phenyl protons of the alkoxo ligand between $\delta 6.45$ and $6.93 \mathrm{ppm}$. Complexes IX-X show complex resonances for methyl and t-butyl groups in both ${ }^{1} \mathrm{H}$ and ${ }^{13} \mathrm{C}$ NMR spectra. The molecular weight in benzene for complex $\mathrm{X}$ was 1390 (theor. 518), so that this complex, and probably also VIII and IX, must be formulated as trimers. The observed NMR behaviour can be interpreted in terms of the existence of a mixture of different isomers with alkoxo bridges.

No assignment can be made for XI-XII.

\section{Experimental}

All the experiments were carried out under vacuum, or under $\mathrm{N}_{2}$ or Ar atmosphere using Schlenk techniques. Solvents were purified by distillation under $\mathrm{N}_{2}$ from sodium benzophenone, except for toluene which was dried over calcium hydride.

$\mathrm{Ta}\left(\eta^{5}-\mathrm{C}_{5} \mathrm{H}_{5}\right) \mathrm{Cl}_{4}$ [5b], $\mathrm{C}_{5} \mathrm{H}_{5} \mathrm{SiMe}_{3}$ and $\mathrm{C}_{5} \mathrm{H}_{4}\left(\mathrm{SiMe}_{3}\right)_{2}$ [6] were prepared as previously described. Commercial cathechol (Riedel) and 4-Me- and 4-Bu ${ }^{\mathrm{t}}$-cathecol (Fluka) were used without purification, but 4,4'-isopropylidene diphenol (Alfa) and $\mathrm{TaCl}_{5}$ (Fluka) were purified by sublimation.

$\mathrm{C}$ and $\mathrm{H}$ analyses were made with a $240 \mathrm{~B}$ Perkin-Elmer microanalyzer. IR spectra were recorded in a 599 Perkin-Elmer spectrophotometer as Nujol mulls between CsI plates. ${ }^{1} \mathrm{H}$ and ${ }^{13} \mathrm{C}$ NMR spectra were run in a FT-80A Varian spectrometer. Molecular weight measurements were carried out with a Knauer vapor pressure osmometer.

$\mathrm{Ta}\left(\eta^{5}-\mathrm{C}_{5} \mathrm{H}_{4} \mathrm{SiMe}_{3}\right) \mathrm{Cl}_{4}(\mathrm{I})$

Method $A$. A toluene $(20 \mathrm{ml})$ solution of $\mathrm{Sn}\left(\mathrm{C}_{5} \mathrm{H}_{4} \mathrm{SiMe}_{3}\right) \mathrm{Bu}_{3}^{\mathrm{n}}(5.42 \mathrm{ml}, 13.9$ mmol) was added dropwise to an orange toluene $(250 \mathrm{ml})$ solution of $\mathrm{TaCl}_{5}(5.00 \mathrm{~g}$, $13.9 \mathrm{mmol})$. A deep yellow solid rapidly separated. Stirring at room temperature 
was continued for $4 \mathrm{~h}$, then the yellow solid was filtered off, repeatedly washed with n-pentane, and identified as complex I. Yield $4.30 \mathrm{~g}, 80 \%$.

Method B. A toluene solution $(20 \mathrm{ml})$ of $\mathrm{C}_{5} \mathrm{H}_{4}\left(\mathrm{SiMe}_{3}\right)_{2}(4.40 \mathrm{~g}, 20.9 \mathrm{mmol})$ was slowly added to an orange toluene $(500 \mathrm{ml})$ solution of $\mathrm{TaCl}_{5}(7.5 \mathrm{~g}, 20.9 \mathrm{mmol})$. After $12 \mathrm{~h}$ stirring at room temperature the brown solution was filtered then evaporated almost to dryness to give a yellow crystalline solid. The solid was filtered off, repeatedly washed with n-pentane, and identified as complex I. Yield: $7.50 \mathrm{~g}$, $80 \%$.

$\mathrm{Ta}\left(\eta^{5}-\mathrm{C}_{5} \mathrm{H}_{5}\right) \mathrm{Cl}_{2}\left(4-\mathrm{R}-\mathrm{C}_{6} \mathrm{H}_{3} \mathrm{O}_{2}\right), \mathrm{R}=\mathrm{H}, \mathrm{Me}, \mathrm{Bu} u^{t}(I I-I V)$

$4-\mathrm{RC}_{6} \mathrm{H}_{3}(\mathrm{OH})_{2}(1.29 \mathrm{mmol})$ was added to a toluene $(100 \mathrm{ml})$ suspension of $\mathrm{Ta}\left(\eta^{5}-\mathrm{C}_{5} \mathrm{H}_{5}\right) \mathrm{Cl}_{4}(0.50 \mathrm{~g}, 1.29 \mathrm{mmol})$. The mixture was stirred for $8 \mathrm{~h}$ at $90-95^{\circ} \mathrm{C}$ during which $\mathrm{HCl}$ was evolved. The resulting green solids were filtered off washed with n-pentane, and characterized as complexes II-IV. Yields $75 \%$.

$\mathrm{Ta}\left(\eta^{5}-\mathrm{C}_{5} \mathrm{H}_{4} \mathrm{SiMe}_{3}\right) \mathrm{Cl}_{2}\left(4-\mathrm{R}-\mathrm{C}_{6} \mathrm{H}_{3} \mathrm{O}_{2}\right), \mathrm{R}=\mathrm{H}, \mathrm{Me}, \mathrm{Bu}^{t}(\mathrm{~V}-\mathrm{VII})$

$2.00 \mathrm{mmol}$ of $4-\mathrm{RC}_{6} \mathrm{H}_{3}(\mathrm{OH})_{2}$ were added to a toluene $(25 \mathrm{ml})$ solution of $\mathrm{Ta}\left(\eta^{5}-\mathrm{C}_{5} \mathrm{H}_{4} \mathrm{SiMe}_{3}\right) \mathrm{Cl}_{4}(0.92 \mathrm{~g}, 2.0 \mathrm{mmol})$. The mixture was stirred for $4 \mathrm{~h}$, at $90-95^{\circ} \mathrm{C}$, and the solution was then filtered and evaporated to $\sim 5 \mathrm{ml}$. Addition of petroleum ether and cooling gave deep green $(\mathrm{R}=\mathrm{H})$ or red $\left(\mathrm{R}=\mathrm{Me}, \mathrm{Bu}^{\mathrm{t}}\right)$ crystals, which were identified as complexes V-VII. Yields $95 \%$.

$\mathrm{TaCl}_{3}\left(4-\mathrm{R}_{-} \mathrm{C}_{6} \mathrm{H}_{3} \mathrm{O}_{2}\right), \mathrm{R}=\mathrm{H}, \mathrm{Me}, \mathrm{Bu}^{t}(\mathrm{VIII}-\mathrm{X})$

4- $\mathrm{RC}_{6} \mathrm{H}_{3}(\mathrm{OH})_{2}(6.95 \mathrm{mmol})$ was added to a toluene $(150 \mathrm{ml})$ solution of $\mathrm{TaCl}_{5}$ $(2.5 \mathrm{~g}, 6.95 \mathrm{mmol})$. The solution was stirred for $4 \mathrm{~h}$ at $90-95^{\circ} \mathrm{C}$ then filtered. Concentration of the filtrate to ca. $5 \mathrm{ml}$ and addition of hexane $(5 \mathrm{ml})$ gave orange microcrystals of the title compounds VIII-X. Yields $65 \%$.

$\left[\mathrm{TaCpCl}_{3}\right]_{2}\left[\left(\mathrm{C}_{6} \mathrm{H}_{4} \mathrm{O}\right)_{2} \mathrm{CMe}_{2}\right] \mathrm{Cp}=\eta^{5}-\mathrm{C}_{5} \mathrm{H}_{5}, \eta^{5}-\mathrm{C}_{5} \mathrm{H}_{4} \mathrm{SiMe}_{3}(\mathrm{XI}-\mathrm{XII})$

$\mathrm{Me}_{2} \mathrm{C}\left(\mathrm{C}_{6} \mathrm{H}_{4} \mathrm{OH}\right)_{2}(0.17 \mathrm{~g}, 0.75 \mathrm{mmol})$ was added to toluene $(70 \mathrm{ml})$ solutions of $\mathrm{TaCpCl}_{4}(1.50 \mathrm{mmol})$ and the mixture was stirred for $6 \mathrm{~h}$ under reflux. When evolution of $\mathrm{HCl}$ was complete the insoluble brown or green solids were filtered off, washed twice with petroluem ether $\left(50-60^{\circ} \mathrm{C}\right)$, and identified as complexes XI-XII. Yields $90 \%$.

\section{Acknowledgement}

The authors acknowledge financial support from the Comisión Asesora de Investigación Científica y Técnica. Ref. 2001-83.

\section{References}

1 (a) R.J.H. Clark, The Chemistry of Titanium and Vanadium, Elsevier, Amsterdam, 1968; (b) R.J.H. Clark, D.C. Bradley and P. Thornton, The Chemistry of Titanium, Zirconium and Hafnium, Pergamon, Oxford, 1975; (c) R.J.H. Clark, S. Moorhouse, and J.D. Stockwell, J. Organomet. Chem. Libr., 3 (1977) 223; (d) J.C. Daran, K. Prout, A. Delian, M.L.H. Green and N. Siganporia, J. Organomet. Chem., 136 (1977) C4.

2 Z. Cossee, J. Catal, 3 (1964) 80.

3 M. Basso Bert and D. Gervais, J. Organomet. Chem., 165 (1979) 209. 
4 A.K. Rappe and W.A. Goddard III., J. Am. Chem. Soc., 104 (1982) 448.

5 (a) M.J. Bunker, A. De Cian and M.L.H. Green, J. Chem. Soc. Chem. Commun., (1977) 59; (b) M.J. Bunker, A. DeCian, M.L.H. Green, J.J.E. Moreau and N. Siganporia, J. Chem. Soc. Dalton Trans., (1980) 2155.

6 A.M. Cardoso, R.J.H. Clark and S. Moorhouse, J. Chem. Soc. Dalton Trans., (1980) 1156.

7 (a) E.R. Lippincott and R.D. Nelson, Spectrochim. Acta, 10 (1958) 307; (b) H.P. Fritz, Adv. Organomet. Chem., 1 (1964) 239.

8 F.A. Cotton and T.J, Marks, J. Am. Chem. Soc., 91 (1969) 7281.

9 (a) D.A. Edwards and R.T. Ward, J. Chem. Soc. A, (1970) 1617; (b) A. Antiñolo, M. Fajardo, A. Otero and P. Royo, J. Organomet. Chem., 265 (1984) 35.

10 (a) D.F. Ball, P.L. Goggin, D.C. McKean, and L.A. Woodward, Spectrochim. Acta, 16 (1960) 1358; (b) H. Burger, Organometal. Chem. Rev., 3 (1968) 425.

11 C.G. Barraclough, D.C. Bradley, J. Lewis and J.M. Thomas, J. Chem. Soc., (1961) 2601.

12 C.T. Lynch, K.S. Mazdiyasni, J.S. Smith and W.J. Crawford, Anal Chem., 36 (1964) 2332.

13 M.F. Lappert, C.J. Pickett, P.I. Riley and P.I.W. Yarrow, J. Chem. Soc. Dalton, (1981) 805.

14 R.J. Abraham and P. Loftus, Proton and Carbon-13 NMR spectroscopy, Heyden, London, 1978, p. 28. 